\title{
Examining service innovation competencies of Turkish deposit banks with fuzzy ANP, fuzzy TOPSIS and fuzzy VIKOR methods
}

\author{
Hasan Dinçer ${ }^{1}$, Ümit Hacıoğlu ${ }^{2}$, Serhat Yüksel ${ }^{3}$ \\ 1, 2, 3 İstanbul Medipol University, Istanbul, Turkey
}

\author{
Keywords \\ Balanced scorecard \\ Service innovation competency \\ Banking \\ Fuzzy ANP \\ Fuzzy TOPSIS \\ Fuzzy VIKOR \\ Received: 6 December 2018 \\ Accepted: 7 January 2019 \\ Published: 20 February 2019
}

\begin{abstract}
This study aimed to rank the service innovation issues of deposit banks in Turkey. In this context, 26 deposit banks of Turkey are analyzed by considering 16 different balanced scorecard-based criteria. Regarding the methodology, the fuzzy ANP method is used to measure the significance of dimensions and criteria. It is defined that the most significant dimension is performance. It is also seen that organizational compliance (D3) is in the last rank. Additionally, return on investment (C1), profitability (C2), and customer expectations (C5) have the highest significance. These alternatives are ranked by considering fuzzy TOPSIS and fuzzy VIKOR methods. The results of both these methods are very similar. It is concluded that there is not a comparative advantage among the banks regarding the ownership type. For example, the best bank (F15) is a foreign bank, whereas the worst bank (F13) is another foreign bank. Similar to this situation, some private banks (P1, P7, P8) have successful performance while others (P4, P5) have weak performance. The new service development concept will probably become more important in the future. Hence, this study has significant results by focusing on a very important topic for the banking sector.
\end{abstract}

\section{INTRODUCTION}

Service innovation is a very significant issue for almost all companies. The main reason is that globalization led to high competition between the companies in all industries (Ayuningrat, Noermijati., \& Hadiwidjojo, 2016; LamberthCocca \& Meiren, 2017). Because of this situation, it can be said that in order to increase competitive power, companies should take some actions, such as service innovation (Ryu \& Lee, 2018). Otherwise, these companies cannot be preferred by the customers. Hence, it will not possible for these companies to survive in the market (Bernik, Azis, Kartini, \& Harsanto, 2015; Yuksel, 2016).

While considering this situation emphasized below, it is understood that evaluating the performance of the companies regarding service innovation is crucial. Most of the meth- ods to achieve the performance consider only financial aspects. However, it can be said that these kinds of methods are not sufficient to achieve this objective. Within this framework, the popularity of balanced scorecard method increases since non-financial issues are also considered in this process (Dinçer, Hacıoğlu, \& Yüksel, 2017; Jingnan, Yunus, \& Kamal, 2018).

This study aims to analyze Turkish banking sector for service innovation. For this purpose, 16 different criteria considering balanced scorecard dimensions are determined. Additionally, fuzzy ANP, TOPSIS and VIKOR methods are used. The criteria are assessed by using fuzzy ANP. Moreover, fuzzy TOPSIS and VIKOR approaches are considered for ranking different banking groups (state, foreign and private) regarding service innovation.

\footnotetext{
*corresponding author: Hasan Dinçer

†email: hdincer@medipol.edu.tr
} 
This study has six different parts. After the introduction part, balanced scorecard approach will be detailed. In this part, four different balanced scorecard dimensions are explained. In the third part, literature is reviewed. The fourth part fuzzy ANP, TOPSIS and VIKOR methods are identified. Moreover, in the fifth part, the details of analysis results are explained. In the conclusion part, suggestions are shared based on these results.

\section{Balanced Scorecard Approach}

Especially in the last decades, competition among the companies increased very much due to the globalization. Therefore, measuring the performance of the companies play a more significant role to recognize any deficiency before it causes bigger problems. Within this framework, it is understood that classical performance measurement methods are not sufficient to satisfy this condition. The main is that these classical methods mainly focus on the financial situation of the companies while measuring the performance.

The significant difference between the balanced scorecard method from the others is that it also includes non-financial issues in addition to the financial factors. The term "balanced" refers to the condition that this method gives balanced importance to financial and non-financial aspects. This method mainly includes following four different dimensions (Sánchez-Márquez, Guillem, Vicens-Salort, \& Vivas, 2018; Tangpornpaiboon \& Puttanapong, 2016).

- Finance: The financial performance is analyzed. It helps to learn whether there is a problem in the company regarding financial aspect (Yüksel, 2016).

- Customer: It analyzes the quality of the image of the companies. Within this framework, it concentrates on the expectations of the customers to increase customer satisfaction (Dincer, Yüksel, \& Martinez, 2019; Kuo \& Chen, 2015). - Internal Process: In this dimension, employee participation plays an important role. This situation contributes both the performance of the employees and the companies. When employee participate any aspects in the company, it increases the motivation of them. On the other side, by considering different ideas of the companies, company can reach its objectives more easily (Dinçer \& Yüksel, 2018; Kozina, 2017).

- Learning and Growth: This dimension defines qualification of the employees and adaption of the companies to any changes in the market (Alahoul, Azizan, \& Alwi, 2016; Dincer, Yuksel, \& Cetiner, 2019).

\section{LITERATURE REVIEW}

Service innovation concept is considered for many different aspects. Griffin and Page (1996) identified new services as investments. Therefore, they analyzed the returns of these investments. Y. Liu and Yang (2009) emphasized the aspect that successful service innovation contributes the profitability of the companies. Moreover, Tajeddini (2011) underlined that service innovation provided cost efficiencies. Furthermore, Griffin (1997) also determined the same conclusions.

Furthermore, some other studies emphasized the effect of new service development on customer relationship. De Brentani (1995) identified that if new service development process could performed successfully, it helps to meet customer demands. Furthermore, Wu, Tzeng, and Chen (2009) determined that effective service innovation process increases customer satisfaction. Similarly, Y. Liu and Yang (2009), Wu et al. (2009) showed that service innovation provides long term effective relationship with the customers.

Additionally, the influence of service innovation on organizational compliance is also emphasized in many different studies. For example, Homburg and Kuehnl (2014), Y. Liu and Yang (2009) and Perks and Riihela (2004) underlined that it has a positive effect on personnel motivation. Schilling and Hill (1998) defined that with service innovation, employees understand the goals of organization. Edvardsson, Meiren, Schäfer, and Witell (2013) stated that employees should be considered in this aspect. Similar to these studies, Melton and Hartline (2010) and Stevens and Dimitriadis (2004) also underlined that employee participation in this process improves the quality of this process. Also, some researchers also considered the importance of technological improvement in new service development. Brown and Eisenhardt (1995) determined that in service innovation projects, market-based databases should be considered and that underlined that for this purpose, technological improvement is crucial. Similar to these studies, S. Liu (2012), Van Riel and Lievens (2004), Van Den Ende (2003) and Ittner and Larcker (1997) identified that with the help of technological improvement, data flow in new service development process can be provided effectively. On the other side, Ku czmarski (1992) focused on the importance of professional training activities for the employees. Consequently, it is identified that many different studies focus on new service development concept in different aspects. For instance, some of them underline the importance of financial situation while some others concentrate on the customer relationship in this process. In addition to these 
subjects, organizational compliance and the importance of training are also taken into the consideration. Therefore, a new study which analyzes all these concepts together in service innovation process. Within this context, it is obvi- ous that balanced scorecard approach helps to achieve this objective since it has all these concepts. Table 1 gives information about key performance indicators of service innovation competencies.

TABLE 1. Key performance indicators of service innovation competencies

\begin{tabular}{|c|c|c|c|}
\hline $\begin{array}{l}\text { Per- } \\
\text { spec- } \\
\text { tive }\end{array}$ & Service Innovation Competencies & Indicators & Studies \\
\hline \multirow[t]{4}{*}{$\begin{array}{l}\text { Finan- } \\
\text { cial }\end{array}$} & \multirow[t]{4}{*}{ Performance } & $\begin{array}{l}\text { Return on In- } \\
\text { vestment }\end{array}$ & $\begin{array}{l}\text { Griffin and Page (1996), Oktar and Yüksel (2015), } \\
\text { Yüksel (2017) }\end{array}$ \\
\hline & & Profitability & $\begin{array}{l}\text { Y. Liu and Yang (2009), C. Storey and Kelly (2001), } \\
\text { Zengin and Yüksel (2016) }\end{array}$ \\
\hline & & $\begin{array}{l}\text { Competitive } \\
\text { Advantage }\end{array}$ & $\begin{array}{l}\text { Dinçer and Yüksel (2018), Tajeddini (2011), } \\
\text { Tajeddini (2011), Kitsios, Doumpos, Grigoroudis, } \\
\text { and Zopounidis (2009), C. Storey and Kelly (2001), } \\
\text { Yüksel, Mukhtarov, Mammadov, and Özsarı (2018) }\end{array}$ \\
\hline & & $\begin{array}{l}\text { Cost Effective- } \\
\text { ness }\end{array}$ & $\begin{array}{l}\text { Kuester, Schuhmacher, Gast, and Worgul (2013), } \\
\text { Y. Liu and Yang (2009), Tajeddini (2011), Yuksel and } \\
\text { Zengin (2017) }\end{array}$ \\
\hline \multirow[t]{4}{*}{$\begin{array}{l}\text { Cus- } \\
\text { tomer }\end{array}$} & \multirow[t]{4}{*}{ Market issues } & $\begin{array}{l}\text { Customer } \\
\text { Expectation }\end{array}$ & $\begin{array}{l}\text { Alam and Perry (2002), De Brentani (1995), } \\
\text { Edvardsson et al. (2013), Emir, Dincer, Hacioglu, and } \\
\text { Yuksel (2015) }\end{array}$ \\
\hline & & Satisfaction & $\begin{array}{l}\text { Cheng, Chen, and Tai Tsou (2012), Dincer (2018), } \\
\text { Y. Liu and Yang (2009), Sigala (2012),Wu et al. (2009) }\end{array}$ \\
\hline & & Practice & $\begin{array}{l}\text { Edvardsson et al. (2013), Griffin (1997), Jaw, Lo, } \\
\text { and Lin (2010), Makkonen and Komulainen (2014), } \\
\text { C. D. Storey and Easingwood (1996), Tunay and Yük- } \\
\text { sel (2017) }\end{array}$ \\
\hline & & Commitment & $\begin{array}{l}\text { Edvardsson et al. (2013), Heskett, Sasser, and Hart } \\
\text { (1990), Y. Liu and Yang (2009) }\end{array}$ \\
\hline \multirow{5}{*}{$\begin{array}{l}\text { Inter- } \\
\text { nal } \\
\text { Factors }\end{array}$} & \multirow[t]{5}{*}{ Organizational Issues } & Compatibility & $\begin{array}{l}\text { De Brentani (1995), Homburg and Kuehnl (2014), } \\
\text { LY. Liu and Yang (2009), Perks and Riihela (2004) }\end{array}$ \\
\hline & & & \\
\hline & & Clearity & $\begin{array}{l}\text { Homburg and Kuehnl (2014), Limpibunterng and } \\
\text { Johri (2009), Schilling and Hill (1998), Smith, Fis- } \\
\text { chbacher, and Wilson (2007) }\end{array}$ \\
\hline & & Contribution & $\begin{array}{l}\text { Edvardsson et al. (2013), De Brentani (1995), Melton } \\
\text { and Hartline (2010), Page (1993), C. Storey and } \\
\text { Hughes (2013), Stevens and Dimitriadis (2004) }\end{array}$ \\
\hline & & $\begin{array}{l}\text { Encourage- } \\
\text { ment }\end{array}$ & $\begin{array}{l}\text { Denison and Mishra (1995), De Brentani (1995), } \\
\text { Melton and Hartline (2010), Page (1993), Stevens } \\
\text { and Dimitriadis (2004) }\end{array}$ \\
\hline \multirow[t]{5}{*}{$\begin{array}{l}\text { Learn- } \\
\text { ing }\end{array}$} & \multirow[t]{5}{*}{ IT Competency } & $\begin{array}{l}\text { Communica- } \\
\text { tion }\end{array}$ & $\begin{array}{l}\text { Edvardsson et al. (2013), S. Liu (2012), Stevens and } \\
\text { Dimitriadis (2004) }\end{array}$ \\
\hline & & Data & $\begin{array}{l}\text { Edvardsson et al. (2013), S. Liu (2012), Kitsios et al. } \\
\text { (2009) }\end{array}$ \\
\hline & & Training & Alam (2012), Kuczmarski (1992), Wu et al. (2009) \\
\hline & & Technologic & Ittner and Larcker (1997), S. Liu (2012), Van Riel and \\
\hline & & Development & $\begin{array}{l}\text { Lievens (2004), Van Den Ende (2003), YUKSEL and } \\
\text { Özsarı (2017) }\end{array}$ \\
\hline
\end{tabular}




\section{RESEARCH METHODOLOGY Fuzzy ANP Method}

People face many difficulties in order to make decision. The main reason is that they have to consider lots of difficult situation at the same time in this process. ANP aims to make decisions in complex conditions. In addition to this situation, clusters can also affect each other in ANP method (Saaty, 1990). The details of ANP system are given below (Chang, Kuo, Wu, \& Tzeng, 2015). First of all, the problem should be explained in detail. Within this scope, the purpose, criteria and sub criteria related to this problem should be identified. Moreover, interaction between the elements is taken into the consideration. As a result, a supermatrix can be created. After that, a weighted matrix is developed by using the importance of the elements. These matrixes are illustrated below. In these matrixes, "a" represent criteria whereas "w" shows the weights (Dincer, Hacioglu, \& Yuksel, 2016).

$A=\left(a_{i j}\right)_{n x n}\left[\begin{array}{ccc}a_{11} & \cdots & a_{1 n} \\ \vdots & \ddots & \vdots \\ a_{n 1} & \cdots & a_{n n}\end{array}\right]$

$\mathrm{V}\left(\mathrm{M} \geq \mathrm{M}_{1}, \mathrm{M}_{2}, \ldots \mathrm{M}_{\mathrm{k}}\right)=\mathrm{V}\left[\left(\mathrm{M} \geq \mathrm{M}_{1}\right)\right.$ and $\left(\mathrm{M} \geq \mathrm{M}_{2}\right)$ and $\ldots$

d- The normalization of these vectors can be provided as below.

$\mathrm{w}=\left(\mathrm{d}\left(\mathrm{A}_{1}\right), \mathrm{d}\left(\mathrm{A}_{2}\right)_{2 \ldots}, \mathrm{d}\left(\mathrm{A}_{\mathrm{n}}\right)\right)^{\mathrm{T}}$

\section{Fuzzy TOPSIS Method}

This approach is used to make decisions in complex environment. Hwang and Yoon developed this method in 1981. It refers to the first letters of "technique for order of preference by similarity to ideal solution". The main advantage of this method is to use and make comments to the about results easily. In the analysis process, both positive and negative ideal solutions are generated (Dincer et al., 2016). In the equation below, $\widetilde{\mathrm{X}}_{i j}$ shows the value for criterion " $j$ " and alternative " $i$ ". Additionally, it can be said that there are $\mathrm{K}$ decision makers.

$\widetilde{\mathrm{X}}_{i j}=\frac{1}{K}+\left(\widetilde{\mathrm{X}}_{i j}^{1}+\widetilde{\mathrm{X}}_{i j}^{2}+\widetilde{\mathrm{X}}_{i j}^{3}+\cdots+\widetilde{\mathrm{X}}_{i j}^{K}\right)$ Where $i=$ $1,2,3, . . \mathrm{m}$ and $j=1,2,3 . \mathrm{n}$

$\widetilde{\mathbf{W}}_{j}=\frac{1}{K}+\left(\widetilde{\mathrm{W}}_{j}^{1}+\tilde{\mathrm{W}}_{j}^{2}+\tilde{\mathrm{W}}_{j}^{3}+\cdots+\widetilde{\mathrm{W}}_{j}^{K}\right)$

While using these fuzzy weights, fuzzy decision matrix can be generated. The details are shown below. In this equation, "C" represents criteria while " $\mathrm{A}$ " gives information about the alternatives.
$A=\left(a_{i j}\right)_{n x n}\left[\begin{array}{ccc}w_{1} a_{11} & \cdots & w_{1} a_{1 n} \\ \vdots & \ddots & \vdots \\ w_{n} a_{n 1} & \cdots & w_{n} a_{n n}\end{array}\right]$

In this process, Chang's fuzzy extent analysis is considered which is also detailed below (Chang et al., 2015).

a- "Fuzzy Synthetic Extent" (Si) is identified. The calculation is shown below.

$\mathrm{S}_{\mathrm{i}}=\left(\sum_{j=1}^{m} a_{i j}\right) \times\left(\sum_{p=1}^{n} \sum_{j=1}^{m} a_{p j}\right)^{-1}$

$\sum_{j=1}^{m} a_{p j}=\left(\sum_{j=1}^{m} l_{j}, \sum_{j=1}^{m} m_{j}, \sum_{j=1}^{m} u_{j}\right)$

$\sum_{p=1}^{n} \sum_{j=1}^{m} a_{p j}=\left(\sum_{j=1}^{n} l_{j}, \sum_{j=1}^{n} m_{j}, \sum_{j=1}^{n} u_{j}\right)$

$\left(\sum_{p=1}^{n} \sum_{j=1}^{m} a_{p j}\right)^{-1}=$

$\left(1 / \sum_{j=1}^{n} l_{j}, 1 / \sum_{j=1}^{n} m_{j}, 1 / \sum_{j=1}^{n} u_{j}\right)$

b- The details of the degree of possibility is illustrated below.

$\left(M_{1} \geq M_{2}\right)=\left\{\begin{array}{cc}1, & m_{1} \geq m_{2} \\ \frac{l_{2}-u_{1}}{m_{1}-u_{1}-m_{2}-l_{2}}, & m_{1}<m_{2}, u_{1} \geq l_{2} \\ 0, & \text { otherwise, }\end{array}\right.$ c- It is calculated as following

$\left.\left(\mathrm{M} \geq \mathrm{M}_{\mathrm{k}}\right)\right]=\min \mathrm{V}\left(\mathrm{M} \geq \mathrm{M}_{\mathrm{i}}\right)$

$\widetilde{\mathrm{D}}=\begin{gathered}A_{1} \\ \vdots \\ A_{m}\end{gathered}\left[\begin{array}{ccc}\mathrm{C}_{1} & \cdots & \mathrm{C}_{\mathrm{n}} \\ \widetilde{\mathrm{X}}_{11} & \cdots & \widetilde{\mathrm{X}}_{1 n} \\ \vdots & \ddots & \vdots \\ \widetilde{\mathrm{X}}_{m 1} & \cdots & \widetilde{\mathrm{X}}_{m n}\end{array}\right]$

In the following step, fuzzy decision matrix is normalized by using the following equations.

$\tilde{\mathbf{r}}_{i j}=\left(\frac{a_{i j}}{c_{i j}^{*}}+\frac{b_{i j}}{c_{i j}^{*}}+\frac{c_{i j}}{c_{i j}^{*}}\right)$

$c_{i j}^{*}=\sqrt{\sum_{i=1}^{m} c_{i j}^{2}}$

Just then, positive and negative solutions are calculated with the formulas below.

$A^{+}=\left(\widetilde{V}_{1}^{+}, \widetilde{V}_{2}^{+}, \widetilde{V}_{3}^{+}, \ldots, \widetilde{V}_{n}^{+}\right)$and

$A^{-}=\left(\widetilde{\mathrm{V}}_{1}^{-}, \widetilde{\mathrm{V}}_{2}^{-}, \widetilde{\mathrm{V}}_{3}^{-}, \ldots, \widetilde{\mathrm{V}}_{n}^{-}\right)$

where $\tilde{V}_{j}^{+}=(1,1,1)$ and $\tilde{V}_{j}^{-}=(0,0,0)$

$D_{i}^{*}=\sum_{j=1}^{n} d\left(\widetilde{\mathrm{V}}_{i j}, \widetilde{\mathrm{V}}_{j}^{*}\right)$

$D_{i}^{-}=\sum_{j=1}^{n} d\left(\widetilde{\mathrm{V}}_{i j}, \widetilde{\mathrm{V}}_{j}^{-}\right)$

In this context, "A+" demonstrates the fuzzy positive ideal solution whereas "A-" shows the fuzzy negative ideal solution. Furthermore, "Di-" refers to the distance from negative ideal solution. Moreover, "Di+" shows the distance from positive ideal solution. Hence, the closeness coefficient can be calculated by using following equations.

$C C_{i}=\frac{D_{i}^{-}}{D_{i}^{+}+D_{i}^{-}}$ 


\section{Fuzzy VIKOR Method}

VIKOR method was developed to make decision in complex situations. Because decision making is not an easy aspect, people face many difficulties when they try to select the best alternative. In VIKOR method, $\mathrm{C}$ refers to the criteria whereas A shows the alternatives. The different steps of this method are detailed below (Dincer et al., 2016). In the first step, the criteria are identified as following.

$f_{i}^{*}=\max f_{i j}$ and $f_{i}^{-}=\min f_{i j}$

On the other side, for the cost issue, the following equations are considered.

$f_{i}^{*}=\min f_{i j}$ and $f_{i}^{-}=\max f_{i j}$

In the second step, $\mathrm{Sj}$ and $\mathrm{Rj}$ values are calculated as below. In these equations, $\mathrm{w}$ represents weights of the criteria.

$$
\begin{aligned}
& \mathrm{S}_{\mathrm{j}}=\sum_{i=1}^{n} \mathrm{w}_{\mathrm{i} \frac{\left(f_{*}^{*}-f_{i j}\right)}{\left(f_{*}^{*}-f_{i}^{-}\right)}} \\
& R_{j}=\max \frac{\mathrm{w}_{\mathrm{i}}\left(f_{i}^{*}-f_{i j}\right)}{\left(f_{i}^{*}-f_{i}^{-}\right)}
\end{aligned}
$$

In the third step, the index value (Qj) is calculated as below. $Q_{j}=\frac{v\left(S-S^{*}\right)}{S^{-}-S^{*}}+\frac{(1-v)\left(R_{j}-R^{*}\right)}{R^{-}-R^{*}}$

$S^{*}=\min _{j} S_{j}$ and $S^{-}=\max _{j} S_{j}$

$R^{*}=\min _{j} R_{j}$ and $R^{-}=\max _{j} R_{j}$

In the fourth step, the values are ranked.

\section{RESULTS AND DISCUSSION}

The first phase of the analysis includes the fuzzy ANP methodology to measure the relative importance of dimensions and criteria. The project team has been also been defined as a decision-maker group to appoint the linguistic terms. The summary results can be seen in Table 2 .

TABLE 2. The weights of criteria

\begin{tabular}{lllll}
\hline \hline Dimensions & Weights & Criteria & Local Weights & Global Weights \\
\hline Financial & 0,34 & Return on Investment & 0,33 & 0,11 \\
& & Profitability & 0,28 & 0,10 \\
& & Competitive Advantage & 0,23 & 0,08 \\
Customer & \multirow{4}{*}{0,27} & Cost Effectiveness & 0,15 & 0,05 \\
& & Customer Expectation & 0,44 & 0,12 \\
& & Satisfaction & 0,32 & 0,08 \\
& & Practice & 0,18 & 0,05 \\
Internal Factors & \multirow{2}{*}{0,18} & Commitment & 0,07 & 0,02 \\
& & Compatibility & 0,44 & 0,08 \\
& & Clearity & 0,23 & 0,04 \\
& & Contribution & 0,19 & 0,03 \\
Learning & \multirow{4}{*}{0,21} & Encouragement & 0,14 & 0,03 \\
& & Communication & 0,29 & 0,06 \\
& Data & 0,29 & 0,06 \\
& Training & 0,22 & 0,05 \\
& & Technologic Development & 0,20 & 0,04 \\
\hline \hline
\end{tabular}

Table 2 shows that performance dimension (D1) has the highest importance in the balanced scorecard perspectives while the organizational compliance (D3) has the weakest weight of new service development competencies. Accordingly, the return on investment (C5) and customer expectation (C8) are the most importance criteria as the commitment (C8) has the weakest criterion with 0.02 .
Following phase continues with the ranking the alternatives by using the fuzzy TOPSIS and fuzzy VIKOR methods comparatively. Both methods used the linguistic terms provided from the group decision. The following steps of the fuzzy TOPSIS have been applied to rank alternatives by calculating the negative $D_{1}^{-}$and positive $D_{1}^{*}$ ideal solution as well as the closeness coefficient $C C_{1}$.

TABLE 3. The values of $D_{1}^{*}, D_{1}^{-}, C C_{1}$ and ranking the alternatives

\begin{tabular}{llllll}
\hline \hline Alternatives & Ownership & $D_{1}^{*}$ & $D_{1}^{-}$ & $C C_{1}$ & Ranking \\
\hline A1 & S1 & 15,84 & 0,17 & 0,01053 & 4 \\
A2 & S2 & 15,84 & 0,16 & 0,01030 & 6 \\
A3 & S3 & 15,86 & 0,14 & 0,00897 & 11 \\
\hline \hline
\end{tabular}


Table 3. Continue.

\begin{tabular}{llllll}
\hline \hline Alternatives & Ownership & $D_{1}^{*}$ & $D_{1}^{-}$ & $C C_{1}$ & Ranking \\
\hline A4 & P1 & 15,83 & 0,18 & 0,01096 & 3 \\
A5 & P2 & 15,91 & 0,10 & 0,00649 & 20 \\
A6 & P3 & 15,89 & 0,12 & 0,00738 & 15 \\
A7 & P4 & 15,91 & 0,10 & 0,00618 & 22 \\
A8 & P5 & 15,92 & 0,09 & 0,00572 & 24 \\
A9 & P6 & 15,84 & 0,16 & 0,01019 & 7 \\
A10 & P7 & 15,83 & 0,18 & 0,01128 & 2 \\
A11 & P8 & 15,84 & 0,17 & 0,01048 & 5 \\
A12 & F1 & 15,90 & 0,11 & 0,00695 & 16 \\
A13 & F2 & 15,92 & 0,09 & 0,00569 & 25 \\
A14 & F3 & 15,90 & 0,11 & 0,00693 & 17 \\
A15 & F4 & 15,90 & 0,11 & 0,00683 & 18 \\
A16 & F5 & 15,88 & 0,13 & 0,00824 & 13 \\
A17 & F6 & 15,86 & 0,15 & 0,00924 & 9 \\
A18 & F7 & 15,88 & 0,13 & 0,00837 & 12 \\
A19 & F8 & 15,86 & 0,15 & 0,00919 & 10 \\
A20 & F9 & 15,89 & 0,12 & 0,00757 & 14 \\
A21 & F10 & 15,91 & 0,10 & 0,00648 & 21 \\
A22 & F11 & 15,86 & 0,15 & 0,00946 & 8 \\
A23 & F12 & 15,90 & 0,11 & 0,00680 & 19 \\
A24 & F13 & 15,93 & 0,08 & 0,00516 & 26 \\
A25 & F14 & 15,92 & 0,09 & 0,00578 & 23 \\
A26 & F15 & 15,82 & 0,18 & 0,01130 & 1 \\
\hline \hline
\end{tabular}

In Table 3, "A" shows the alternatives. With respect to the ownership, "S" demonstrates state banks, "P" refers to the private banks and " $F$ " focuses on the foreign banks. A26 is the best bank in service innovation competencies, and
A24 has the worst degree of the service innovation performance. The fuzzy VIKOR is used to provide the comparative results of the banks' new service development competencies as well. The results are demonnstrated in Table 4.

TABLE 4. The values of $S_{i}, R_{i}$ and $Q_{i}$ and ranking the alternatives

\begin{tabular}{llllll}
\hline \hline Alternatives & Ownership & $S_{i}$ & $R_{i}$ & $Q_{i}$ & Ranking \\
\hline A1 & S1 & 0,274 & 0,064 & 0,250 & 6 \\
A2 & S2 & 0,304 & 0,064 & 0,270 & 7 \\
A3 & S3 & 0,444 & 0,082 & 0,478 & 11 \\
A4 & P1 & 0,170 & 0,061 & 0,161 & 3 \\
A5 & P2 & 0,729 & 0,083 & 0,673 & 19 \\
A6 & P3 & 0,624 & 0,083 & 0,604 & 14 \\
A7 & P4 & 0,776 & 0,097 & 0,793 & 20 \\
A8 & P5 & 0,837 & 0,117 & 0,968 & 24 \\
A9 & P6 & 0,289 & 0,061 & 0,240 & 5 \\
A10 & P7 & 0,238 & 0,041 & 0,072 & 2 \\
A11 & P8 & 0,252 & 0,061 & 0,215 & 4 \\
A12 & F1 & 0,675 & 0,082 & 0,628 & 16 \\
A13 & F2 & 0,847 & 0,117 & 0,974 & 25 \\
A14 & F3 & 0,675 & 0,083 & 0,637 & 17 \\
A15 & F4 & 0,708 & 0,117 & 0,882 & 21 \\
\hline \hline
\end{tabular}


Table 4. Continue..

\begin{tabular}{llllll}
\hline \hline Alternatives & Ownership & $S_{i}$ & $R_{i}$ & $Q_{i}$ & Ranking \\
\hline A16 & F5 & 0,513 & 0,083 & 0,530 & 13 \\
A17 & F6 & 0,385 & 0,061 & 0,302 & 9 \\
A18 & F7 & 0,474 & 0,083 & 0,504 & 12 \\
A19 & F8 & 0,399 & 0,061 & 0,312 & 10 \\
A20 & F9 & 0,640 & 0,084 & 0,622 & 15 \\
A21 & F10 & 0,749 & 0,117 & 0,910 & 22 \\
A22 & F11 & 0,355 & 0,061 & 0,282 & 8 \\
A23 & F12 & 0,697 & 0,083 & 0,651 & 18 \\
A24 & F13 & 0,885 & 0,117 & 1,000 & 26 \\
A25 & F14 & 0,796 & 0,115 & 0,923 & 23 \\
A26 & F15 & 0,127 & 0,041 & 0,000 & 1 \\
\hline \hline
\end{tabular}

TABLE 5. Comparative results of service innovation competencies with the fuzzy TOPSIS and fuzzy VIKOR

\begin{tabular}{llll}
\hline \hline Alternatives & Ownership & Ranking with FTOPSIS & Ranking with FVIKOR \\
\hline A1 & S1 & 4 & 6 \\
A2 & S2 & 6 & 7 \\
A3 & S3 & 11 & 11 \\
A4 & P1 & 3 & 3 \\
A5 & P2 & 20 & 19 \\
A6 & P3 & 15 & 14 \\
A7 & P4 & 22 & 20 \\
A8 & P5 & 24 & 24 \\
A9 & P6 & 7 & 5 \\
A10 & P7 & 2 & 2 \\
A11 & P8 & 5 & 4 \\
A12 & F1 & 16 & 16 \\
A13 & F2 & 25 & 25 \\
A14 & F3 & 17 & 17 \\
A15 & F4 & 18 & 21 \\
A16 & F5 & 13 & 13 \\
A17 & F6 & 9 & 9 \\
A18 & F7 & 12 & 12 \\
A19 & F8 & 10 & 10 \\
A20 & F9 & 14 & 15 \\
A21 & F10 & 21 & 22 \\
A22 & F11 & 8 & 8 \\
A23 & F12 & 19 & 18 \\
A24 & F13 & 26 & 26 \\
A25 & F14 & 23 & 23 \\
A26 & F15 & 1 & 1 \\
\hline \hline & & & \\
& & & \\
\hline
\end{tabular}

In Table 4, A26 is the best in the new service development competencies while A24 has the weakest performance in the banking sector.
Table 5 presents the comparative results of two integrated decision making approaches under the fuzzy environment. FANP-FTOPSIS and FANP-FVIKOR models give the same re- 
sults for selecting the best and the worst bank in the performance measurement. Thus, both approaches could provide the coherent results for ranking the banks in the performance of service innovation competencies.

\section{CONCLUSION}

Nowadays, banks all around the world have to give very much importance to service innovation concept to increase the competitive advantage. Otherwise, they cannot find a chance to survive in such a severe competition. This study aimed to assess the service innovation performance. In the analysis process, 26 Turkish deposit banks are examined. Also, 16 different criteria are identified by considering 4 different dimensions of balanced scorecard approach. Moreover, fuzzy ANP, fuzzy TOPSIS and fuzzy VIKOR are considered to achieve this purpose.

It is concluded that performance (D1) has the highest importance (0.34). Furthermore, it is also determined that internal factors have the lowest weight (0.18). Furthermore, it is also identified that return on investment (C1), profitability (C2) and customer expectations (C5) are the most important criteria. However, commitment (C8), contribution (C11) and encouragement (C12) are accepted as the least important criteria. It is also defined that the results of fuzzy TOPSIS and fuzzy VIKOR are very similar. In other words, both of these two methods give similar ranking results for the banks with respect to new service development competencies. In spite of this situation, by analyzing the performance of the banks according to the ownership type, it is identified there is not a comparative advantage of one type to another. For instance, the best bank in both methods is a foreign bank (F15). However, another foreign bank (F13) is also determined as the worst bank. Similarly, a private bank (P7) has the second highest performance while another private bank (P5) has a very bad performance.

\section{IMPLICATIONS}

The concept of service innovation has a high popularity in banking sector. Banks have to consider this situation to increase power. Additionally, it can also be said that new service development concept will probably become more important in the future. Hence, this study has significant results by focusing on a very important topic for banking sector.

\section{REFERENCES}

Alahoul, M. H. M., Azizan, N., \& Alwi, N. H. (2016). Factors that affect the use of Malaysian e-learning websites by visually impaired users in the transfer of Islamic knowledge. Journal of Advanced Research in Social Sciences and Humanities, 1(1), 30-40. doi:https://doi.org/10.26500/jarssh-01-2016-0104

Alam, I. (2012). New service development in India's business-to-business financial services sector. Journal of Business and Industrial Marketing, 27(3), 228-241. doi:https://doi.org/10.1108/08858621211207243

Alam, I., \& Perry, C. (2002). A customer-oriented new service development process. Journal of Services Marketing, 16(6), 515-534. doi:https://doi.org/10.1108/08876040210443391

Ayuningrat, M. P., Noermijati., \& Hadiwidjojo, D. (2016). Green product innovation's effect on firm performance of managerial environmental concern and green communication. Journal of Administrative and Business Studies, 2(2), 56-63. doi: https://doi.org/10.20474/jabs-2.2.1

Bernik, B., Azis, Y., Kartini, D., \& Harsanto, B. (2015). Managing innovation of SMEs in creative industry for interactive game subsector and TV and radio subsector based on local wisdom in development of competitiveness business (case study SMEs in Bandung). International Journal of Business and Administrative Studies, 1(2), 49-53. doi:https://doi.org/ 10.20469/ijbas.10001-2

Brown, S. L., \& Eisenhardt, K. M. (1995). Product development: Past research, present findings, and future directions. Academy of Management Review, 20(2), 343-378. doi:https://doi.org/10.5465/amr.1995.9507312922

Chang, B., Kuo, C., Wu, C.-H., \& Tzeng, G.-H. (2015). Using fuzzy analytic network process to assess the risks in enterprise resource planning system implementation. Applied Soft Computing, 28, 196-207. doi:https://doi.org/10.1016/j.asoc .2014.11.025

Cheng, C. C., Chen, J.-S., \& Tai Tsou, H. (2012). Market-creating service innovation: Verification and its associations with new service development and customer involvement. Journal of Services Marketing, 26(6), 444-457. doi:https://doi.org/ $10.1108 / 08876041211257927$

De Brentani, U. (1995). New industrial service development: Scenarios for success and failure. Journal of Business Research, 32(2), 93-103. doi:https://doi.org/10.1016/0148-2963(93)00040-8 
Denison, D. R., \& Mishra, A. K. (1995). Toward a theory of organizational culture and effectiveness. Organization Science, 6(2), 204-223. doi:https://doi.org/10.1287/orsc.6.2.204

Dincer, H. (2018). Hhi-based evaluation of the european banking sector using an integrated fuzzy approach. Kybernetes, 48(6), 1195-1215. doi:https://doi.org/10.1108/k-02-2018-0055

Dincer, H., Hacioglu, U., \& Yuksel, S. (2016). Balanced scorecard-based performance assessment of Turkish banking sector with analytic network process. International Journal of Decision Sciences and Applications, 1(1), 1-21. doi:https:// doi.org/10.4018/ijsecsr.2016070101

Dinçer, H., Hacıoğlu, Ü., \& Yüksel, S. (2017). Balanced scorecard based performance measurement of european airlines using a hybrid multicriteria decision making approach under the fuzzy environment. Journal of Air Transport Management, 63(4), 17-33. doi:https://doi.org/10.1016/j.jairtraman.2017.05.005

Dinçer, H., \& Yüksel, S. (2018). Comparative evaluation of BSC-based new service development competencies in Turkish banking sector with the integrated fuzzy hybrid MCDM using content analysis. International Journal of Fuzzy Systems, 20(8), 2497-2516. doi:https://doi.org/10.1007/s40815-018-0519-y

Dincer, H., Yuksel, S., \& Cetiner, I. T. (2019). Strategy selection for organizational performance of turkish banking sector with the integrated multi-dimensional decision-making approach. Pennsylvania, PA: IGI Global.

Dincer, H., Yüksel, S., \& Martinez, L. (2019). Balanced scorecard-based analysis about European energy investment policies: A hybrid hesitant fuzzy decision-making approach with quality function deployment. Expert Systems with Applications, 115, 152-171. doi:https://doi.org/10.1016/j.eswa.2018.07.072

Edvardsson, B., Meiren, T., Schäfer, A., \& Witell, L. (2013). Having a strategy for new service developmentdoes it really matter? Journal of Service Management, 24(1), 25-44. doi:https://doi.org/10.1108/09564231311304170

Emir, S., Dincer, H., Hacioglu, U., \& Yuksel, S. (2015). Comparative study of outlier detection algorithms via fundamental analysis variables. International Journal of Research in Business and Social Science, 4(4), 45-60. doi:https://doi.org/ 10.20525/ijrbs.v4i4.462

Griffin, A. (1997). PDMA research on new product development practices: Updating trends and benchmarking best practices. Journal of Product Innovation Management: An International Publication of The Product Development \& Management Association, 14(6), 429-458. doi:https://doi.org/10.1111/1540-5885.1460429

Griffin, A., \& Page, A. L. (1996). Pdma success measurement project: Recommended measures for product development success and failure. Journal of Product Innovation Management, 13(6), 478-496. doi:https://doi.org/10.1111/1540 $-5885.1360478$

Heskett, J., Sasser, W., \& Hart, C. (1990). Service breakthroughs: Changing the rules of the game the free press. New York, NY: The Free Press.

Homburg, C., \& Kuehnl, C. (2014). Is the more always better? A comparative study of internal and external integration practices in new product and new service development. Journal of Business Research, 67(7), 1360-1367. doi:https:// doi.org/10.1016/j.jbusres.2013.08.017

Ittner, C. D., \& Larcker, D. F. (1997). Quality strategy, strategic control systems, and organizational performance. Accounting, Organizations and Society, 22(3-4), 293-314. doi:https://doi.org/10.1016/s0361-3682(96)00035-9

Jaw, C., Lo, J.-Y., \& Lin, Y.-H. (2010). The determinants of new service development: Service characteristics, market orientation, and actualizing innovation effort. Technovation, 30(4), 265-277. doi:https://doi.org/10.1016/j.technovation .2009 .11 .003

Jingnan, W., Yunus, N., \& Kamal, Y. (2018). The relationship between corporate entrepreneurship and innovation in manufacturing companies in perak. International Journal of Business and Economic Affairs, 3(1), 33-39. doi:https://doi.org/ 10.24088/ijbea-2018-31004

Kaplan, R. S., \& Norton, D. P. (2007). Balanced scorecard. New York, NY: Springer.

Kitsios, F., Doumpos, M., Grigoroudis, E., \& Zopounidis, C. (2009). Evaluation of new service development strategies using multicriteria analysis: Predicting the success of innovative hospitality services. Operational Research, 9(1), 17-33. doi:https://doi.org/10.1007/s12351-008-0025-3

Kozina, M. (2017). Methodology for managing a business strategy within high-tech companies. International Journal of Business and Economic Affairs, 2(6), 366-377. doi:https://doi.org/10.24088/ijbea-2017-26006 
Kuczmarski, R. J. (1992). Prevalence of overweight and weight gain in the United States. The American Journal of Clinical Nutrition, 55(2), 495S-502S. doi:https://doi.org/10.1093/ajcn/55.2.495s

Kuester, S., Schuhmacher, M. C., Gast, B., \& Worgul, A. (2013). Sectoral heterogeneity in new service development: An exploratory study of service types and success factors. Journal of Product Innovation Management, 30(3), 533-544. doi:https://doi.org/10.1111/jpim.12005

Kuo, M. P., \& Chen, Y. M. (2015). A study on the relationships among body sensory experience, customer satisfaction and customer loyalty-beauty SPA center as an example. International Journal of Business and Administrative Studies, 1(2), 61-67. doi:https://doi.org/10.20469/ijbas.10003-2

Lamberth-Cocca, S., \& Meiren, T. (2017). Towards a reference model for agile new service development using the example of e-mobility service systems. Procedia CIRP, 64, 259-264. doi:https://doi.org/10.1016/j.procir.2017.03.052

Limpibunterng, T., \& Johri, L. M. (2009). Complementary role of organizational learning capability in New Service Development (NSD) process. The Learning Organization, 16(4), 326-348. doi:https://doi.org/10.1108/09696470910960419

Liu, S. (2012). The relationship between strategic type and new service development competence: A study of chinese knowledge intensive business services. Service Business, 6(2), 157-175. doi:https://doi.org/10.1007/s11628-011 $-0122-\mathrm{x}$

Liu, Y., \& Yang, R. (2009). Competing loyalty programs: Impact of market saturation, market share, and category expandability. Journal of Marketing, 73(1), 93-108. doi:https://doi.org/10.1509/jmkg.73.1.93

Makkonen, H., \& Komulainen, H. (2014). Networked new service development process: A participant value perspective. Management Decision, 52(1), 18-32. doi:https://doi.org/10.1108/md-03-2013-0183

Melton, H. L., \& Hartline, M. D. (2010). Customer and frontline employee influence on new service development performance. Journal of Service Research, 13(4), 411-425. doi:https://doi.org/10.1177/1094670510369378

Oktar, S., \& Yüksel, S. (2015). Yilinda rusya'da yaşanan bankacilik krizi ve oncu gostergeleri. Marmara University Journal of Economic \& Administrative Sciences, 37(2), 34-40.

Page, A. L. (1993). Assessing new product development practices and performance: Establishing crucial norms. Journal of Product Innovation Management, 10(4), 273-290. doi:https://doi.org/10.1016/0737-6782(93)90071-w

Perks, H., \& Riihela, N. (2004). An exploration of inter-functional integration in the new service development process. The Service Industries Journal, 24(6), 37-63. doi:https://doi.org/10.1080/0264206042000299176

Ryu, H.-S., \& Lee, J.-N. (2018). Understanding the role of technology in service innovation: Comparison of three theoretical perspectives. Information \& Management, 55(3), 294--307. doi:https://doi.org/10.1016/j.im.2017.08.003

Saaty, T. L. (1990). Decision making for leaders: The analytic hierarchy process for decisions in a complex world. Pittsburgh, PA: RWS Publications.

Sánchez-Márquez, R., Guillem, J. A., Vicens-Salort, E., \& Vivas, J. J. (2018). A statistical system management method to tackle data uncertainty when using key performance indicators of the balanced scorecard. Journal of Manufacturing Systems, 48, 166--179. Retrieved from https://doi.org/10.1016/j.jmsy.2018.07.010

Schilling, M. A., \& Hill, C. W. (1998). Managing the new product development process: Strategic imperatives. Academy of Management Perspectives, 12(3), 67-81. doi:https://doi.org/10.5465/ame.1998.1109051

Sigala, M. (2012). Exploiting web 2.0 for new service development: Findings and implications from the Greek tourism industry. International Journal of Tourism Research, 14(6), 551-566. doi:https://doi.org/10.1002/jtr.1914

Smith, A. M., Fischbacher, M., \& Wilson, F. A. (2007). New service development: From panoramas to precision. European Management Journal, 25(5), 370-383. doi:https://doi.org/10.1016/j.emj.2007.06.007

Stevens, E., \& Dimitriadis, S. (2004). New service development through the lens of organisational learning: Evidence from longitudinal case studies. Journal of Business Research, 57(10), 1074-1084. doi:https://doi.org/10.1016/ s0148-2963(03)00003-1

Storey, C., \& Hughes, M. (2013). The relative impact of culture, strategic orientation and capability on new service development performance. European Journal of Marketing, 47(5/6), 833-856. doi:https://doi.org/10.1108/ 03090561311306903

Storey, C., \& Kelly, D. (2001). Measuring the performance of new service development activities. Service Industries Journal, 21(2), 71-90. doi:https://doi.org/10.1080/714005018 
Storey, C. D., \& Easingwood, C. J. (1996). Determinants of new product performance: A study in the financial services sector. International Journal of Service Industry Management, 7(1), 32-55. doi:https://doi.org/10.1108/ 09564239610109401

Tajeddini, K. (2011). Customer orientation, learning orientation, and new service development: An empirical investigation of the swiss hotel industry. Journal of Hospitality and Tourism Research, 35(4), 437-468. doi:https://doi.org/10.1177/ 1096348010380599

Tangpornpaiboon, S., \& Puttanapong, N. (2016). Financial contagion of the global financial crisis from the US to other developed countries. Journal of Administrative and Business Studies, 2(1), 48-55. doi:https://doi.org/10.20474/jabs $-2.1 .5$

Tunay, K. B., \& Yüksel, S. (2017). The relationship between corporate governance and foreign ownership of the banks in developing countries. Contaduría y administración, 62(5), 1627-1642. doi:https://doi.org/10.1016/j.cya.2017.05 .007

Van Den Ende, J. (2003). Modes of governance of new service development for mobile networks: A life cycle perspective. Research Policy, 32(8), 1501-1518. doi:https://doi.org/10.1016/s0048-7333(02)00156-7

Van Riel, A. C., \& Lievens, A. (2004). New service development in high tech sectors: A decision-making perspective. International Journal of Service Industry Management, 15(1), 72-101. doi:https://doi.org/10.1108/09564230410523349

Wu, H.-Y., Tzeng, G.-H., \& Chen, Y.-H. (2009). A fuzzy MCDM approach for evaluating banking performance based on balanced scorecard. Expert Systems with Applications, 36(6), 10135-10147. doi:https://doi.org/10.1016/j.eswa.2009.01.005

Yuksel, S. (2016). Bankacllk krizlerinin erken uyarı sinyalleri: Turkiye uzerine bir uygulama. Istanbul, Turkey: Akademisyen Kitabevi.

Yüksel, S. (2016). Bankaların takipteki krediler oranını belirleyen faktörler: Türkiye için bir model önerisi. Bankacılar Dergisi, 98(6), 41-56.

Yüksel, S. (2017). Determinants of the credit risk in developing countries after economic crisis: A case of Turkish banking sector. New York, NY: Springer.

Yüksel, S., Mukhtarov, S., Mammadov, E., \& Özsarı, M. (2018). Determinants of profitability in the banking sector: An analysis of post-soviet countries. Economies, 6(3), 41-50. doi:https://doi.org/10.3390/economies6030041

YUKSEL, S., \& Özsarı, M. (2017). Türkiye'nin kredi notunu etkileyen faktörlerin mars yöntemi ile belirlenmesi. Politik Ekonomik Kuram, 1(2), 16-31. doi:https://doi.org/10.30586/pek.356929

Yuksel, S., \& Zengin, S. (2017). Influencing factors of net interest margin in Turkish banking sector. International Journal of Economics and Financial Issues, 7(1), 178-191.

Zengin, S., \& Yüksel, S. (2016). Likidite riskini etkileyen faktörler: Türk bankacıllk sektörü üzerine bir inceleme. Istanbul University Journal, 15(29), 77-95. 